\title{
MORAL HAZARD DALAM PEMBIAYAAN SISTEM BAGI HASIL (MUDHARABAH DAN MUSYARAKAH) PADA BPRS
}

\author{
Enny Puji Lestari., M.E.Sy \\ Fakultas Ekonomi dan Bisnis Islam IAIN Metro Lampung \\ ennypujilestari@metrouniv.ac.id
}

Eka Yuli Astuti, MH

Fakultas Ekonomi dan Bisnis Islam IAIN Metro Lampung echayoelia@gmail.com

\author{
Diterima: Oktober 2019
}

Direvisi : November 2019

Diterbitkan: November 2019

\begin{abstract}
Moral Hazard is one of the factors causing the low application of financing in the profit sharing system, namely the Akad Mudharabah and Musyarakah.Research seeks to uncover the phenomenon holistically by describing it through non-numeric language in the context and natural paradigm.In previous studies, the Agreement on Mudharabah and Mutanaqisah was carried out between the customer and the bank, which increased in the year 2014-2015.In this study, Mudharabah suffered from 2019 in May-August 2019. While the financing of Musyarakah increased.

The results showed that the moral behavior of the customer's hazard to the BPRS is one of the risks that the bank has to pay itself in relation to the financing system for the outcome. In the application of financing is appropriate to what has been prescribed by Islam because it has been fulfilled in the form of the Akad Mudharabah and Musyarakah on the Bprs. Factors that encourage the occurrence of moral hazard is caused by the factor of the customer and financial institution itself. The customer's factor is due to his personal interests. While the financial institutions factor, because of the lack of vigilance from the management of financial institutions in providing funds to give the side of the moral hazard to the customers. This is due to the optimal monitoring system, information asymmtric, and limitation of the scope of contract contents.

Keywords: Moral hazard, Musyarakah; Mudharabah, BPRS
\end{abstract}

\begin{abstract}
ABSTRAK
Moral Hazard merupakan salah satu faktor penyebab rendahnya penerapan pembiayaan pada sistem bagi hasil yaitu pada akad mudharabah dan musyarakah. Penelitian yang berusaha mengungkap fenomena secara holistik dengan cara mendeskripsikannya melalui bahasa non numerik dalam konteks dan paradigma alamiah. Pada penelitian terdahulu menggambarkan tentang akad dalam pembiaayaan mudharabah dan musyarakah yang dilakukan antara nasabah dan bank mengalami kenaikan pada tahun 2014-2015. Sedangkan dalam penelitian ini pembiyaan mudharabab mengalami penurunun di tahun 2019 pada bulan Mei-Agustus 2019. Sedangkan pada pembiayaan musyarakah mengalami kenaikan. Hasil penelitian menunjukkan bahwa perilaku moral hazard nasabah pada BPRS merupakan salah satu risiko yang harus ditanggung oleh pihak bank itu sendiri terkait pembiayaan pada sistem bagi hasil. Dalam penerapan pembiayaannya sudah sesuai terhadap apa yang telah disyariatkan Islam karena telah terpenuhinya rukun pada sistem akad mudharabah serta musyarakah pada BPRS. Faktor-faktor yang mendorong terjadinya moral hazard disebabkan oleh faktor nasabah dan lembaga keuangan itu sendiri. Faktor nasabah cendrung terjadi karena kepentingan pribadinya. Sedangkan faktor lembaga keuangan, karena kurangnya sikap kewaspadaan dari manajeman lembaga keuangan dalam memberikan dana sehingganya menimbulkan sisi moral hazard kepada nasabah. Hal tersebut dikarenakan tidak optimalnya sistem monitoring, asymmtric informasi, dan keterbatasan cakupan isi kontrak.
\end{abstract}

Kata Kunci: Moral hazard, Musyarakah; Mudharabah, BPRS

\section{A. Latar Belakang Masalah}

Perbankan syariah memberikan penyaluran dana dengan produk mudharabah dan musyarakah kepada masyarakat atau perusahaan dengan konsep bagi hasil dan margin, selain itu ada produk lain yaitu tabungan dan deposito juga dengan konsep bagi hasil. ${ }^{1}$ Didalam

${ }^{1}$ Muammar Arafat Yusmad, Aspek Hukum Perbankan Syariah Dari Teori Ke Praktik (Yogyakarta: Budi Utama, 2018), 100. 
oprasional pembiayaan syariah pada saat bank menyalurkan pembiayaan kepada nasabah, maka sumber terjadinya risiko gagal bayar adalah ketika nasabah debitur kehilangan kemampuan untuk membayar cicilan pinjamannya kepada bank. ${ }^{2}$

Proses pembiayaan yang sudah berjalan tidak terlepas dari sebuah risiko yang akan menyebabkan terjadinya kemungkinan peyimpangan yang melatar belakangi kerugian. Risiko pembiayaan hanya berlaku untuk akad berbasis utang, yaitu pada akad qordul hasan, jual beli muajjal, dan jual beli salam. Sedangakn pada berbasis syirkah yaitu mudharabah dan musyarakah tidak masuk dalam resiko gagal bayar, hal ini disebabkan debitur tidak diwajibkan mengembalikan modal yang diberikan kepada bank, akan tetapi berdasarkan pada keuntuangan dan kerugian yang di dapatkan. ${ }^{3}$ Adapun bahaya yang terjadi dalam pembiayaan mudharabah dan musyarakah dalam sistem bagi hasil adalah bahaya fisik (physical hazard), bahaya moral (moral hazard), bahaya morale (morale hazard), dan bahaya karena hukum (legal hazard) ${ }^{4}$

Di dalam perkembangan bank syari'ah di Indonesia pada operasional dalam produk berbasis bagi hasil mengalami penurunan, berdasarkan penelitian yang dilakukan oleh Asmirawati and Sumarlin, kecilnya implementasi operasional bagi hasil yaitu pembiayaan berbasis mudharabah dan musyarakah bila dibandingkan dengan produk bank syari'ah lainnya seperti produk murabahah, ijarah, istishna, dan qardh, dan produk tabungan. Turunnya kontrak pembiayaan berbasis bagi hasil, ditunjukan dengan bukti besarnya kontrak pembiayaan mudharabah per Juni 2014 sejumlah 4.312 kontrak dan pada juni 2015 kenaikannya sangatlah minim yaitu sejumlah 14.906 kontrak, kontrak tersebut jika dibandingkan dengan pembiayaan berbasis jual beli sangatlah jauh berbeda, sebab untuk kontrak pembiayaan murabahah pada tahun 2015 tercatat mencapai 117.770 kontrak. ${ }^{5}$ Dari data OJK bahwa pembiayaan mudharabah mengalami penurununan dan pembiayaan musyarakah mengalami peningkatan.

Tabel 1

Kegiatan Usaha Bank Umum Syariah dan Unit Usaha Syariah - SPS 2019 (Sharia Commercial Bank and Sharia Business Unit Operations ) Miliar Rp (Billion IDR)

\begin{tabular}{|c|c|c|c|c|c|}
\hline No & Produk & Mei 2019 & Juni 2019 & Juli 2019 & Agustus 2019 \\
\hline 1 & Mudharabah & 14.155 & 13.973 & 13.884 & 13.441 \\
\hline 2 & Musyarakah & 137.889 & 140.199 & 141.177 & 142.856 \\
\hline
\end{tabular}

Sumber: Otoritas Jasa Keuangan Agustus $2019^{6}$

Berdasarkan data diatas, pada bulan Mei 2019 kegiatan usaha pada BPRS dana yang digulirkan sebanyak Rp.14.155 miliar, dan mengalami penurunan pada Agustus 2019 sebanyak Rp.13.441 miliar. Oleh karenanya kontrak yang dilakukan antara nasabah dan bank mengalami penurununan, dimana penyebab rendahnya pengimplikasian produk pembiayaan bagi hasil akibat moral hazard.

Minimnya implementasi mudharabah dan musyarakah tersebut tidak lain karena tingginya resiko calon pengelola dana (moral hazard). Akad mudharabah dan musyarakah kedua-duanya berkaitan segala sesuatu yang berhubungan dengan keagenan atau suatu perantara usaha.

2 Imam Wahyu dkk, Manajemen Risiko Bank Islam (Jakarta: Penertbit Salemba Empat, 2013), 74.

${ }^{3}$ Wahyu dkk, 90.

${ }^{4}$ Kasidi, Manajemen Risiko (Semarang: Penerbit Ghalia Indonesia, 2010), 6-7.

5 Asmirawati and Sumarlin, "PERILAKU MORAL HAZARD NASABAH PADA PEMBIAYAAN BERBASIS BAGI HASIL PADA PERBANKAN SYARIAH,” LAA MAISYIR : Jurnal Ekonomi Islam 5, no. 1 (June 15, 2018): 121-45, https://doi.org/10.24252/laamaisyir.v5i1a6.

${ }^{6}$ Otoritas Jasa Keuangan, Statistik. Perbankan Syariah, Sharia Banking Statistic, 2019, 9. 
Dalam suatu kerja sama akad mudharabah penyaluran pembiayaan modal $100 \%$ sepenuhnya dari bank. Lembaga keuangan memberikan hak seutuhnya kepada mudharib untuk menjalankan usahanya tanpa adanya keterlibatan shahibul maal, sehingga pihak mudharib lebih mengetahui tentang usaha yang akan dijalankannya sedangkan pihak bank tidak mengetahui seutuhnya dibandingkan dengan mudharib. Kemudian apabila terjadi suatu kerugian maka kerugian tersebut sepenuhnya ditanggung oleh bank, sehingga dalam hal ini resiko pembiayaan bagi hasil cenderung cukup besar. Hal tersebutlah yang dapat membuka peluang bagi pengelola untuk melakukan penyimpangan.

Kegagalan bayar dapat disebabkan oleh faktor kemampuan keuangan (ability to pray) dan/atau keriadaan itikad baik dari debitur untuk membayar (willingness to pay). Kondisi ini muncul karena adanya moral hazard dari debitur. Moral hazard dapat berasal dari sifat dasar yang dimiliki oleh debitur atau disebakan oleh faktor lain. Risiko moral hazard yang muncull karena sifat kolektif ini selanjutnya dikenal dengan istilah risiko sistematis atau risiko portofolio. ${ }^{7}$

Perilaku moral hazard merupakan perilaku dari unsur kesengajaan yaitu ketidak konsekuennya atau tidak bertanggung jawab atas apa yang dilakukannya. Perilaku moral hazard yang dilakukan nasabah pada dasarnya akan membuat bank untuk dapat lebih berhati-hati lagi dalam menyalurkan pembiayaan, karena akan sangat berpengaruh terhadap profit bank dan dapat menjadi resiko yang semakin tinggi. Besarnya pembiayaan memperbesar resiko terhadap kualitas pembiayaan bank syari'ah. Hal ini menjadikan suatu peringatan bagi bank syari'ah agar adanya perbaikan dalam proses penyaluran pembiayaan.

Mustafa Edwin N. dan Ranti Wiliasih memaparkan bahwa dari sikap ketidak hati-hatian terhadap penyaluran dana pihak ketiga dapat tergolong sebagai tindakan moral hazard secara tidak langsung. Apabila sikap untuk kehati-hatian dari menajemen pihak bank kurang, dalam hal ini penyaluran pembiayaan dana kepada nasabah secara tidak langsung mengakibatkan timbulnya moral hazard, sehingga dapat meningkatkan tingkat kredit macet. ${ }^{8}$ Setiap nasabah yang ingin melakukan pembiayaan di BPRS, maka nasabah tersebut harus mengikuti tata cara yang sudah ditentukan oleh pihak BPRS. Diantaranya nasabah harus memenuhi dan melengkapi dari syarat-syarat yang telah ditetapkan oleh pihak BPRS apabila nasabah tersebut akan melakukan pembiayaan. Dalam oprasionalnya pihak bank sudah melakukan hal yang sangat maksimal dalam melakukan observasi terhadap seseorang ataupun pihak badan, akan tetapi dalam pelaksanaanya masih saja terjadi masalah pembiayaan yang tidak diinginkan.

Pada moral bazard nasabah, pengambilan data baik yang bersumber dari nasabah dan masyarakat sekitar dengan melihat karakter nasabah memberikan info yang cukup kuat dari data yang diminta, sehingga tidak diragukan lagi ketika nasabah tersebut akan melakukan pembiayaan. Akan tetapi kepercayaan yang sudah diberikan pihak bank tidak sesuai dengan hasil analisis yang sudah dilakukan oleh tim marketing, sehingganya pada saat akan melakukan pembiayaan nasabah tidak melakukan pembayaran pada saat sudah jatuh tempo dan berdampak moral hazard. Oleh karenanya, penelitian ini ingin mengetahui penerapan mudharabah dan musyarakah BPRS dan faktor-faktor yang mendorong terjadinya moral hazard dalam pembiayaan berbasis bagi hasil pada BPRS. Tujuan penelitian ini diakukan adalah agar mengetahui dari penerapan terhdap akad mudharabah dan akad musyarakah pada BPRS, dan

7 Wahyu dkk, Manajemen Risiko Bank Islam, 93.

${ }^{8}$ Mustafa Edwin Nasution and Ranti Wiliasih, "PROFIT SHARING DAN MORAL HAZARD DALAM PENYALURAN DANA PIHAK KETIGA BANK UMUM SYARIAH DI INDONESIA,” Jumal Ekonomi Dan Pembangunan Indonesia 7, no. 2 (January 1, 2007): 106, 
untuk mengetahui faktor-faktor yang menyebabkan terjadinya moral hazard sehingganya menimbulkan konflik dalam pembiayaan sistem bagi hasil pada BPRS.

Pada penelitian kualitatif, bahwasannya pendekatan kualitatif adalah aturan penelitian dalam mengasilkan suatu data deskriptif yaitu baik berupa beberapa kata yang tertulis atau tertulis dari seseorang maupun karakteristik yang diamati. ${ }^{9}$ Pendekatan kualitatif merupakan metode penelitian dalam usaha mengungkap beberapa fenomena yang secara holistik mendeskripsikannya beradasarkan bahasa tidak numerik dalam suatu konteks dan paradigma secara alamiah. Dapat dikatakan juga bahwa terkait penelitian metode kualitatif merupakan penelitian alamiah. ${ }^{10}$ Kemudian peneliti menganalisis data dan menginterprestasikan data yang didapatkan. Data yang telah didapat kemudian dianalisis dari serangkaian data yang ada dan digambarkan secara menyeluruh dari fenomena yang terjadi pada penerapan pembiayaan pada sistem mudharabah dan akad musyarakah serta faktor yang mendorong terjadinya moral hazard pada pembiayaan sistem bagi hasil.

Berkenaan terhadap hal tersebut, Taylor dan Bogdan memaparkan bahwa penelitian metode kualitatif merupakan tata cara penelitian untuk menghasilkan suatu data bersifat deskriptif yang berupa kata-kata secara tertulis ataupun lisan berdasarkan seseorang dan berprilaku dapat dilakukan proses pengamatan dengan diarahkannya terhadap yang melatar belakangi dan individu yang secara utuh (bolistic). ${ }^{11}$ Alasan peneliti menggunakan pendekatan kualitatif yaitu agar peneliti dapat lebih dekat dengan subyek penelitiannya serta dapat lebih peka dan berinteraksi dalam menyesuaikan diri. Penelitian dengan mengungkapkan suatu fenomena dengan cara holistik yaitu dengan mendeskripsikannya berdasarkan bahasa tidak numerik terhadap konteks serta paradigma yang alamiah. Kemudian peneliti menganalisis data dan menginterprestasikan data yang didapatkan. Data yang didapat dianalisis dan dipaparkan secara keseluruhan dari suatu fenomena pada penerapan pemberian pembiayaan akad mudharabah dan akad musyarakah serta faktor yang dapat pendorong terjadinya moral hazard pada pembiayaan sistem bagi hasil.

\section{B. Pembasahan}

\section{Penerapan Pembiayaan Mudharabah Dan Musyarakah Pada BPRS a. Pembiayaan Mudharabah}

Bagi hasil merupakan suatu aturan dilakukannya suatu perjanjian ataupun suatu ikatan kebersamaan didalam melaksanakan sebuah kegiatan dari usaha. Kemudian didalam usaha tersebut adanya perjanjian atas pembagian dari hasil keuntungan yang akan diperoleh antara pihak yang bersangkutan baik dari dua pihak saja maupun lebih. ${ }^{12}$

Pembiayaan mudharabah dan pembiayaan musyarakah memiliki prinsip dari bagi hasil, yang menjadi pembeda utama antara lembaga keuangan syariah dengan lembaga keuangan konvesional. Mudharabah secara etimologis, diperoleh dari bahasa arab artinya melaksanakan perjalanan untuk melakukan perdagangan. Mudharabah atau qiradh tergolong dari kategori kerjasama atau syirkah dengan akad sistem bagi hasil.

Menurut Azzuhaily secara istilah mudharabah yaitu menyerahkan sebagian harta kepada pelaksana dari usaha (amil) agar melaksanakan suatu usaha tertentu dengan

${ }^{9}$ Lexi J Moleong, Metodologi Penelitian Kualitatif (Bandung: PT Remaja Rosdakarya, 2014), 4. 2011), 28 .

${ }^{10}$ Masyhuri and Zainuddin, Metodelogi Penelitian Pendekatan Praktis Dan Aplikatif (Bandung: PT. Refika aditama,

${ }^{11}$ Cholid Narbuko and Abu Achmadi, Metodologi Penelitian (Jakarta: PT. Bumi Aksara, 2007), 46.

${ }^{12}$ Iqbal Taufik and Saija, Dinamika Hukum Islam Indonesia (Yogyakarta: Deepublish, 2016), 116. 
keuntungan yang diperoleh dibagi oleh pihak kerjasama berdasarkan oleh persyaratan yang sudah dibicarakan. Mudharabah diperspektif fiqih merupakan suatu kontrak antara dua kelompok, yaitu investor sebagai pemilik modal yang mempercayai modalnya terhadap mudarib yaitu pengelola untuk dipergunakan dalam aktivitas usaha seperti perdagangan. Sementara itu, keuntungan dari hasil dagang tersebut dibagi berdasarkan apa yang sudah menjadi kesepakatan. Mudharabah adalah bentuk akad suatu pihak yaitu antara dua pihak bahwasannya satu pihak sebagai shahibul maal (pemilik dari modal) dan mempercayai beberapa modalnya agar dikelola dari pihak kedua, yaitu sebagai mudharib (pelaksana usaha), dengan maksud agar memperoleh keuntungan. ${ }^{13}$

Berdasarkan PSAK 105 menyatakan bahwa mudharabah adalah suatu akad dengan bentuk kerjasama dalam bidang usaha, dimana dalam akad tersebut terdapat dua pihak, pemiliki modal atau penyedia modal dikatakan sebagai pihak pertama, sedangkan pihak yang mengelola modal bisa dikatakan sebagai pihak kedua. ${ }^{14}$ Dalam kerja sama tersebut keuntungan dan kerugian akan ditanggung sesuai akad yang telah disepakati antara pihak satu dengan pihak satunya. Namun dalam PSAK 105 disebutkan jika kerugian hanyalah ditanggung oleh shahibul maal sepenuhnya.

Oleh karena itu kerjasama yang biasanya dilakukan oleh suatu lembaga bank syariah tersebut memiliki resiko yang sangat besar terlebih lagi dalam urusan profit bank tersebut. Jika si pengelola tidak mampu menggunakan modalnya dengan baik, maka ancaman terbesarnya adalah terjadi gagal bayar dan akibatnya lembaga keuangan mengalami kerugianPada BPRS pembiayaan ini merupakan bentuk akad pembiayaan sistem bagi hasil $\mathrm{k}$ sebagai pemilik dana biasa disebut dengan shahibul maal yaitu yang menyediakan 100\% modal kepada nasabah untuk usaha atau nasabah sebagai mudharib yaitu sebagai pengelola agar melakukan suatu aktivitas secara produktif atau kegiatan usaha pada syarat bahwa keuntungan dari usaha yang diperoleh akan dibagi kedua pihak yaitu pihak BPRS dan nasabah menurut kesepakatan bersama yang ditentukan dalam akad.

Apabila terjadi suatu kerugian dengan sebab karena proses yang bebar-benar normal dari usaha yaitu bukan disebabkan karena kelalaian ataupun kecurangan dari si pengelola, maka pengelola tersebut haruslah bertanggung jawab secara sepenuhnya terhadap kerugian usaha tersebut. Pembiayaan akad mudharabah ini memiliki resiko yang sangat tinggi, oleh sebab itu harus dilakukan secara sangat berhati-hati dengan penelitian yang baik dan sebenar-benarnya.

Pembiayaan mudharabah merupakan pembiayaan sistem amanah yang disalurkan lembaga keuangan kepada mudharib yang diberikan oleh BPRS secara penuh untuk mendanai usaha nasabah dengan konsep bagi hasil, di dalam kesepakatan dengan jatuh tempo yang termaktub dalam perjanjian akad dan tidak bertentangan dengan syari'at islam.

Di dalam penerapan mudharabah rukun yang dipenuhi yaitu adanya aqid, maq'ud alaih, serta sighat. ${ }^{15}$ Aqid yaitu adanya pengelola dan pemberian pembiayaan berupa dana,

13 Taufik and Saija, 128.

14 Ikatan Akutansi Indonesia, "PSAK 105," 2007, 7

${ }^{15}$ Dwi Agustin Maulida and Abdul Mukti Thabrani, "MEMINIMALISIR RESIKO MORAL HAZARD PADA PEMBIAYAAN MUDHARABAH DI KOPERASI SYARIAH NURI JAWA TIMUR (KSN JATIM) 
sedangkan maq'ud alaih yaitu sistem bagi hasil atau profit yang telah disepakati, kemudian sighat yaitu ijab qabul dari lembaga keuangan (shahibul maal) dan nasabah (mudharib).

\section{b. Pembiayaan Musyarakah}

Musyarakah adalah suatu akad dalam bentuk kerja sama bagi dua pihak ataupun lebih akan suatu usaha tertentu, masing-masing pihak terkait ikut serta memberikan beberapa kontribusi terhadap dana (amal/ expertise) dengan adanya perjanjian bahwa untuk hasil keuntungan dan apabila terjadi risiko maka akan ditanggung secara bersama sesuai dengan kesepakatan. ${ }^{16}$

Akad Mudharabah juga hampir sama dengan akad Musyarakah, dalam PSAK No. $6^{17}$ menyatakan bahwa Musyarakah adalah sebuah akad kerjasama yang dilakukan oleh dua atau lebih pihak yang terikat atas kerjasama. Dimana yang membedakan antara akad Mudharabah dengan Musyarakah adalah dalam akad Musyarakah pihak kedua atau pengelola modal juga bisa memiliki dua peran yakni sebagai shahibul maal dan mudharib (pemilik modal dan pengelola modal). Pembagian keuntungan dilakukan berdasarkan kesepakatan antara pihak yang bersangkutan, kemudian untuk kerugian biasanya akan dibagi berdasarkan porsi dana yang diajukan sebagai modal.

Pada BPRS, pembiayaan ini merupakan bentuk pembiayaan bagi hasil ketika BPRS sebagai pemilik modal atau pemilik dana ikut serta sebagai mitra usaha, membiayai investasi pihak lain. Perjanjian antara nasabah atau pengusaha dengan pihak lembaga keuangan, bahwasannya modal kedua dijadikan satu untuk modal usaha yang akan dikelola bersama-sama. Keuntungan maupun kerugian menjadi tanggungan bersama berdasarkan dengan kesepakatan awal.

Pembiayaan akad musyarakah merupakan suatu perjanjian dalam pembiayaan yang berjalan terus berdasarkan lama usaha yang dibiayai bersama-sama masih beroperasi. Penerapan yang dilakukan BPRS, bahwa musyarakah adalah suatu akad kerjasama antara lembaga keuangan dengan nasabah dan lembaga keuangan menyetui untuk memberikan pembiayaan untuk usaha maupun suatu proyek secara kerjasama dengan nasabah selaku inisiator usaha dengan suatu jumlah pada prosentase akad secara tertentu dari sejumlah total untuk biaya usaha dengan didasari pembagian hasil keuntungan dari suatu usaha atau proyek tersebut yang akan dijalankan tersebut dengan didasarkan pada prosentase sistem pembagian hasil yang sudah ditetapkan awal akad.

\section{Moral Hazard Pada Produk Pembiayaan Sistem Bagi Hasil Pada BPRS}

Moral hazard adalah suatu kondisi yang bersumber dari orang yang bersangkutan yang berkaitan dengan sikap mental atau pandangan hidup serta kebiasaan yang dapat memperbesar kemungkinan terjadinya suatu kerugian. ${ }^{18}$ Moral hazard pada dunia lembaga keuangan awalnya sering dipergunakan dalam dunia bisnis asuransi pada harapan untuk memperoleh klaim dari barang yang sudah terasuransikan. Selain itu, moral hazard juga sering dipergunakan di perspektif embaga keuangan dengan merujuk oleh perilaku dari

PLAKPAK KECAMATAN PEGANTENAN PAMEKASAN," IQTISHADIA: Jurnal Ekonomi \& Perbankan Syariah 2, no. 2 (December 31, 2015): 197, https://doi.org/10.19105/iqtishadia.v2i2.866.

16 Muhammad Syafi'i Antonio, Bank Syariah Dari Teori Ke Praktik (Jakarta: Gema Insani, 2004), 90.

${ }^{17}$ Ikatan Akutansi Indonesia, "PSAK 106," 2007.

${ }^{18}$ Herman Darmawi, Manajemen Risiko (Jakarta: Bumi Aksara, 2010), 25. 
beberapa pihak yang memiliki kepentingan sendiri (stakeholder) seperti dari pihak lembaga keuangan (pemegang pada saham serta manajemen), deposan maupun debitur lembaga keungan dengan menciptakan suatu insentif agar melakukan suatu agenda atupun tindakan dengan tersembunyi dan berlawanan terhadap etika di bisnis serta terhadap hukum yang berlaku. ${ }^{19}$

Penggunaan dari istilah moral hazard awalnya digunakan di bidang asuransi. Moral hazard timbul disebabkan karena seorang individu atau lembaga keuangan tidak konsekuen dengan penuh dan pertanggung jawabannya tidak ada terhadap perbuatannya, dan oleh karenanya hal tersebut cenderung kurang kehati-hatian daam bertindak untuk melepas suatu tanggung jawab dari konsekuensi tindakan seseorang oleh pihak lain. Moral hazard di dunia lembaga keuangan setidaknya bisa digolongkan menjadi 2, yaitu Moral bazard di lembaga keuangan dan moral bazard di nasabah itu sendiri.

Moral hazard nasabah dari segi umumnya timbul di produk pembiayaan sistem akad mudharabah dan akad musyarakah atau biasa disebut profit dan loss sharing. Moral hazard dapat dikatakan sebagai perilaku kriminal pada bidang ekonomi yaitu suatu tindakan oleh pelaku ekonomi yang mengakibatkan suatu kemudharatan, baik kemudharatan terhadap diri sendiri bahkan terhadap pihak lain. Untuk memastikan apakah suatu tindakan didunia perbankan merupakan moral hazard apakah bukan, perlu halnya dari mempelajari prinsip-prinsip pada transaksi berlandaskan Islami, yaitu apakah dihalakan atau yang diharamkan. ${ }^{20}$

Moral Hazard disebut sebagai salah satu faktor utama yang menyebabkan konflik dalam pembiayaan sistem bagi hasil, Moral hazard tersebut membuat resiko pada pembiayaan sistem bagi hasil meningkat karena unsur ketidak pastiaan dan pendapatan yang relative rendah. ${ }^{21}$ Moral hazard merupakan salah satu alasan yang mendasari rendahnya pengaplikasian pada pembiayaan sistem bagi hasil.

a. Mudharabah

Pembiayaan dana dari pihak bank sangat sering terkena risiko, terlebih pada pembiayaan mudharabah yang sering adanya moral hazard yaitu penyimpangan etitud moral. Tingkat potensi dari moral hazard tidaklah kecil ha ini dikarenakan unsur kepentingan tiap pihak. Sehingganya dalam kasus moral hazard akan terkait siapa yang akan melakukan penyimpangan, alasan ia melakukan penyimpangan dan siapa yang akan dirugikan dari perilaku tersebut.

Pembiayaan mudharabah adalah pembiayaan yang paling rentan terhadap risiko moral hazard karena pembiayaan mudharabah yang di aplikasikan di BPRS adalah mudharabah mutlaqah, dimana 100\% modal yang digunakan nasabah dalam menjalankan usahanya adalah modal dari perbankan. Oleh karena itu akad muḍharabah termasuk kelompok Natural Uncertainty Contracts yang tidak ada kepastian untuk pengembaliannya, baik dari segi total keuntungan maupun waktunya.

19 Taswan, Manajemen Perbankan Konsep, Tebnike \& Aplikasi (Yogyakarta: UPP STIM YKPN, 2010), 125.

20 Asmirawati and Sumarlin, "PERILAKU MORAL HAZARD NASABAH PADA PEMBIAYAAN BERBASIS BAGI HASIL PADA PERBANKAN SYARIAH,” 127.

${ }^{21}$ Salman Syed Ali and Islamic Research and Training Institute, eds., Islamic Capital Markets: Products, Regulation \& Development: Proceedings of International Conference Jeddah: Islamic Research and Training Institute, Islamic Development Bank, 2008), 241. 
Akad mudharabah bahwasannya tidak mensyaratkan adanya jaminan serta memberikan hak sepenuhnya kepada nasabah terkait pelaksanaan usaha tanpa adanya campur tangan dari shahibul maall. Kemudian kerugian usaha ditanggung oleh lembaga keuangan, kecuali adanya kesalahan pihak manajemen membuat akad pembiayaan bagi hasil mudharabah ini sangat rentan terkena masalah moral hazard. ${ }^{22}$

Moral hazard peminjam (deabitur) terhadap bank adalah moral hazard yang dilakukan nasabah umumnya dikarenakan adanya asimetri informasi yang sangat tinggi, bahwa bank tidak dapat mendesain bentuk kontrak yang dapat dijadikan pengaman secara sepenuhnya dari dana yang diberikan kepada debitur.

b. Pembiayaan Musyarakah

Moral hazard pada mudharib, melakukan hal-hal yang kurang lebih hanya berkeinginan menguntungkan mudharib itu sendiri sehingganya merugikan pihak shahibul maal, hal ini disebabkan lembaga keuangan yang tidak mengetahui berapa porsi keuntungan secara utuh yang dihasilkan oleh mudharib dari usaha tersebut. ${ }^{23}$

Berbeda dengan akad mudharabah, dalam akad musyarakah pihak nasabah ikut menambahkan terhadap sebagian modalnya sendiri pada modal yang diberikan oleh bank, dengan kondisi ini adanya penambahan modal dari nasabah maka nasabah dapat mengklaim suatu presentase bagi hasi yang lebih besar. Oleh sebab itulah yang mengakibatkan akad pembiayaan pada basis bagi hasil sangat mudah terkena masalah moral hazard.

Sama halnya dengan pembiayaan sitem mudharabah bahwasannya pembiayaan musyarakah juga tidak adanya ketentuan jaminan dalam pembiayaan bagi hasil ini menyebabkan lembaga keuangan di BPRS menghadapi risiko yang sangat tinggi terutama risiko terjadinya moral hazard karena adanya informasi yang asimetri.

\section{Faktor-Faktor Yang Mendorong Terjadinya Moral Hazard Pada Pembiayaan Sistem Bagi Hasil Di BPRS}

Perilaku moral hazard itu sendiri adalah biasanya bagi para pelaku usaha yang dalam usahanya tengah mengalami kemajuan dan biasanya secara otomatis kebanyakan dari mereka lalai terhadap kewajibannya untuk membayar pembiayaan itu kepada pihak bank. Apabila usaha mereka mengalami kemajuan biasanya sifat hawa nafsu mereka akan menjadi semakin kuat, mulai dari berkeinginan untuk membeli rumah, kemudain muncul lagi ingin beli mobil dan seterusnya, hal itulah yang biasanya justru membuat mereka lalai terhadap kewajubannya.

\section{1) Faktor Dari Sisi Nasabah}

Moral hazard terjadi dikarenakan kecenderungan atas perilaku-perilaku nasabah tersebut yang tidak memiliki moral seperti kejujuran yang tidak ada, kepedulian yang tidak ada, ketidaktahuan. BPRS sebagai lembaga keuangan penyaluran pembiaayaan sistem bagi hasil, bank mengaku pernah merasakan nasabah yang berperilaku moral hazard.

22 Siti Aisiyah Suciningtias, "Indikasi Moral Hazard Pada Pembiayaan Mudharabah Dan Murabahah Pada Bank Umum Syariah Di Indonesia," Jurnal Dinamila Ekonomi Dan Bisnis 14, no. 01 (March 2017): 75.

${ }^{23}$ Adiwarman A Karim, Bank Islam Analisis Fiqih Dan Kenangan (Jakarta: PT Raja Grafindo Persada, 2013), 214. 
Disini perilaku moral hazard selain merugikan lembaga keuangan, perilaku moral hazard juga dapat merugikan pihak nasabah yang melakukan perilaku moral hazard itu sendiri. Konsekuensi dari perilaku tersebut nasabah akan terancam di black list oleh BI, dan tentunya nasabah tersebut akan kesulitan dalam memperoleh pembiayaan di seluruh lembaga keuangan. Bahwasannya seseorang yang tidak berprilaku jujur dalam akad mudharabah dikemudian harinya tidak akan mendapat kepercayaan kembali dan tidak dapat ikut bersaing untuk memperoleh pembiayaan untuk kedua kalinya diakad mudharabah sehingga dia tidak akan menerapkan hal tersebut. Sehingganya motivasi atau niat nasabah terhadap pengambilan pembiayaan harus diawali dari niat yang baik dan, kejelasan tujuannya.

Moral hazard seperti ini adalah moral hazard yang benar terjadi sebab kesengajaan dari nasabah itu sendiri. Timbulnya perilaku moral hazard yang dilakukan nasabah pada dasarnya akan membuat lembaga keuangan untuk lebih waspada dalam menyalurkan pembiayaannya, karena risiko yang akan diterima oleh bank dapat semakin tinggi. Asimetri informasi salah satu penyebab fraud yang diterapkan oleh nasabah, hal ini disebabkan karena lembaga keuangan kurang mengetahui usaha yang akan dijalankan oleh mudharibyatu nasabah tersebut. Selain itu juga pada BPRS menyebabkan salah satu perilaku moral hazard nasabah adalah karena adanya peningkatan minat atau perilaku kebutuhan konsumtif nasabah di saat usahanya dijalankan mengalami progress kemajuan, sehingga terdapat beberapa nasabah yang seringkali lupa akan kewajibannya.

Berdasarkan pemaparan diatas dapat dianalisa bahwa Moral hazard tidak hanya timbul akibat faktor sengaja seperti ketidakmauan membayar cicilan/angsuran atau pinjaman, tetapi menunda-nunda untuk membayar angsuran pinjaman termasuk juga dalam moral hazard. Sesungguhnya dalam Islam, orang Islam diajarkan untuk memenuhi semua akad-akad atau sebuah kesepakatan atas dasar kebersamaan. Penjelasan pada firman Allah Swt:QS. Al-Maidah ayat 1:"Wahai orang-orang yang beriman! Penuhilah janji-janji (akad-akad)"Ayat ini, memaparkan bahwa seseorang yang bertaqwa di seru agar melengkapi akad-akad (persetujuan) yang telah di lakukannya. Perjanjian yang dimaksud disini adalah perjanjian yang dilakukan baik kepada Allah maupun kepada sesama manusia.

Pada BPRS moral hazard nasabah sangat dipengaruhi oleh;

a) Sikap tidak bertanggungjawab

Hal yang terlalu sering diterapkan oleh nasabah sebagai salah satu indikasi terjadinya moral hazard adalah ketika mereka sudah diberi kepercayaan (berupa pembiayaan baik mudharobah ataupun musyarokah) maka biasanya mereka enggan untuk memenuhi kewajibannya. Hal tersebut tentu sangat merugikan bagi pihak bank yang bersangkutan. Terlebih lagi jika ada salah satu nasabah yang melakukan tidakan yang tidak bertanggungjawab seperti itu biasanya akan menular ke nasabah yang lainnya. Maka dari itu untuk meminimalisir terjadinya kecurangan/kedzaliman tersebut pihak Bank Indonesia akan segera melakukan black list kepada nasabah yang jika terbukti melakukan tindakan tersebut.

Black list merupakan suatu tindakan atau system yang digunakan oleh Bank Indonesia sebagai hukuman kepada nasabah yang terbukti melakukan hal tersebut. Adapun hukuman yang dimaksud adalah seorang nasabah tidak dapat kembali untuk 
melakukan pembiayaan di Bank manapun. Hal ini tentu akan sangat merugikan juga bagi nasabah jika sewaktu-waktu ingin melakukan pembiayaan.

b) Manipulasi Biaya/Mark-Manipulasi

Biaya/Mark-up Demi mendapatkan keuntungan sebanyak mungkin dengan tanpa mengeluarkan biaya yang juga banyak, maka para nasabah dengan rela memanipulasi harga. Memanipulasi harga yang jelaskan disini maksudnya adalah dengan melakukan kecurangan terhadap harga bahan baku yang akan digunakan dalam suatu usaha. Sejatinya kebanyakan dari mereka tahu jika perbuatan tersebut sangatlah dzalim, baik dari pihak bank maupun untuk dirinya sendiri. Namun kurangnya bekal pengetahuan dan keimanan yang kuat membuat mereka dengan teganya melakukan pemalsuan atau memanipulasi harga

c) Fraud/Memanipulasi jaminan

Faktor yang ketiga ini bisa dikatakan hampir mirip dengan faktor di bagian kedua, hanya yang membedakannya adalah jika Manipulasi Biaya itu dilakukan dengan melakukan pemalsuan biaya terhadap bahan baku, sedangkan Manipulasi Jaminan yaitu dengan mengalihkan tanggung jawab dari si nasabah yang bersangkutan kepada orang yang tidak ada kaitannya dalam akad kerjasama tersebut. KPR (kredit perumahan rakyat) merupakan salah satu bentuk fasilitas yang digunakan dalam kecurangan ini yang sejatinya itu tidak ada. Dengan begitu pembiayaan yang dilakukan oleh nasabah yang memiliki sifat moral hazard tersebut tidak dibayarkan. Segala bentuk kecurangan yang dilakukan oleh si nasabah sejatinya adalah unsur kesengajaan sendiri dari diri nasabah. Oleh karena itu pihak bank dalam menyalurkan pembiayaannya memang harus besar kehati-hatiannya.

\section{2) Faktor Dari Sisi Lembaga Keuangan Itu Sendiri}

Ketidak hati-hatian untuk menyalurkan dana kepada pihak nasabah juga termasuk dalam kategori sebagai suatu tindakan moral hazard yaitu kategori tidak langsung. Kurangnya dari sikap kewaspadaan dari manajeman pihak lembaga keuangan dalam menmberikan dana sehingganya menimbulkan sisi moral hazard kepada nasabah yang secara tidak langsung.

Moral hazard pada tingkat di lembaga keuangan timbul ketika lembaga keuangan sebagai pemilik dana tidak berhati-hati ketika menyalurkan pembiayaan sehingganya berpotensi menyebabkan munculnya moral hazard pada sisi nasabah tersebut dan berisiko terjadinya kerugian. ${ }^{24}$

Jika sikap dari menajemen pihak bank untuk kehati-hatiannya kurang, dengan demikian secara tidak langsung maka dapat mengakibatkan timbulnya moral hazard atas penyaluran pembiayaan kepada nasabah.

Faktor dari sisi lembaga keuangan itu sendiri terjadi disebabkan karena lembaga keuangan sebagai lembaga perantara bagi nasabah yang membutuhkan dana disisi itu juga bank untuk mengoprasikan tugasnya bahwasannya apabila bank mengalami kelebihan dana maka sudah pasti bank akan menyalurkan dana tersebut. Akibat unsur kelebihan dana tersebut, menyebabkan lembaga keuangan di BPRS Madani tidak sepenuhnya melakukan survey dengan maksud untuk mempercepat penyaluran kelebihan dana tersebut.

${ }^{24}$ Suciningtias, "Indikasi Moral Hazard Pada Pembiayaan Mudharabah Dan Murabahah Pada Bank Umum Syariah Di Indonesia," 74. 
Penyaluran pembiayaan bagi hasil lembaga keuangan juga cenderung melakukan penyaluran pembiayaan didasari sifat belas kasihan, dengan sistem kenalan (bersaudara atau teman), karena sesuai prinsip syariah bahwasannya orang islam diajarkan untuk saling membantu, namun jika dibiarkan terus menerus maka juga akan merugikan pihak bank tentunya. Oleh sebab itu pembiayaan sitem bagi hasil ini cenderung rawan terjadinya moral hazard sebab kurangnya kehat-hatian lembaga keuangan dalam proses penyaluran pembiayaan tersebut. Faktor-faktor yang mendorong terjadinya moral hazard dari sisi lembaga keuangan yaitu BPRS, adalah sebagai berikut;

1. Tidak Optimalnya Sistem Monitoring

Sistem monitoring yang tidak optimal merupakan salah satu kategori dari faktor yang menyebabkan munculnya moral hazard. Dari beberapa permasalahan pembiayaan sistem bagi hasil yang terjadi di BPRS Madani Kota Metro dikarenakan kurangnya pengawasan atau kurangnya monitoring terhadap periaku nasabah, kemampuan kerjanya dan kondisi nasabah serta yang lebih utama tentang daya kemampuan nasabah terkait timbal balik pembayaran nantinya, terutama setelah berjalannya akad bagi hasil tersebut. Lembaga keuangan tidak mengetahui tindakan nasabah sepenuhnya karena adanya ketidakpastian dari tindakan nasabah serta hasilnya, karena ada biaya untuk mengawasi tindakan nasabah, hal tersebut dijadikan sebuah kesempatan oleh pihak nasabah untuk bertindak moral hazard.

2. Asymmtric Informasi.

Asymmtric Informasi merupakan faktor penyebab terjadinya moral hazard, hal ini terlihat dari kepemilikan untuk informasi yang tidak singkron antara nasabah dengan pihak bank. Bahwasannya nasabah lebih memiliki informasi yang lebih lengkap dari situasi mereka dibandingkan dengan informasi yang dimiliki bank terkait situasi nasabah tersebut, sehingganya nasabah dapat memanfaatkan hal tersebut untuk mengambil keuntungan dari hal ini. Penyaluran pembiayaan sistem bagi hasil oleh nasabah pada akhirnya nasabah memanipulasi hal tersebut. Oleh sebab itu menyebabkan terjadinya moral hazard yang disebabkan karena kurangnya informasi yang diperoleh oleh BPRS

3. Keterbatasan Cakupan Isi Kontrak

Keterbatasan cakupan pada kontrak adalah faktor terjadinya perilaku moral bazard oleh nasabah. Kurangnya penetapan criteria nasabah menyebabkan nasabah mudah tergolong perilaku moral hazard baik dari sudut pandang BPRS ataupun dari sudut pandang fiqhyah. Kurangnya keterbatasan penetapan dari kriteria nasabah tersebut menyebabkan permasalahan pada pembiayaan basis bagi hasil di BPRS tersebut.

Perilaku moral hazard telah dipaparkan sebelumnya bahwasannya perilaku tersebut seringkali menjadi kebiasaan yang dilakukan oleh nasabah ialah tidak melakukan transaksi secara jujur, tidak adanya rasa peduli terhadap sesama, tidak ada pengetahuan atau tidak adanya rasa keingintahuan dan yang terakhir tentu tidak bisa memiliki hati nurani yang baik. Pada umumnya prilaku moral hazard sering kali merugikan pihak dari bank-nya itu sendiri. Oleh karenya untuk mencegah terjadinya moral hazard diperlukan Sosialisasi sehingga perlu adanya penegasan mengenai kejujuran, tanggung jawab, disiplin. 
Selain itu adaMitigasi Pra-akad, yang merupakan sebuah tindakan yang dilakukan lembaga keuangan guna meminimalisir resiko tersebut. Biasanya bank akan melakukan pendataan bagi calon nasabah yang akan melakukan proses pembiayaan tersebut, biasanya hal yang paling utama dilihat adalah mengenai karakter si calon nasabah tersebut. 5C merupakan suatu prinsip yang paling ditekankan dalam metode ini. Adapun 5C itu merupakan Character, Capacity, Capital, Colateral dan Condition Economy.

Diperlukan ada penegasan terkait dengan jaminan yang diberikan nasabah kepada bank dengan alasan untuk meminimalisir terjadi suatu hal tidak diinginkan seperti tindakan moral hazard, apabila itu tidak diterapkan maka kecil kemungkinan bank akan mengalami resiko kerugian yang cukup besar dan membuat bank itu menjadi bangkrut. Dan alhasil bank tersebut akan tidak mendapat kepercayaan lagi terhadap masyarakat.

Menjadi penting ketika mitigasi pasca akad menjadi perhatian dalam pengawasan secara berkala, dimana pihak bank secara tidak langsung bisa mengetahui bagaimana kondisi usaha yang dijalankan oleh para nasabahnya tersebut. Kemudian penetapan biaya standar adalah hal yang paling ditekankan.

\section{Kesimpulan}

Berdasarkan hasil penelitian dan pembahasan yang telah dijelaskan, maka dapat ditarik kesimpulan bahwasannya Moral hazard disebut sebagai salah satu faktor utama yang menyebabkan resiko pada pembiayaan sistem bagi hasil meningkat karena unsur ketidakpastiaan dan pendapatan yang relatif rendah. Kedepannya tentu diharapkan agar porsi pembiayaan berbasis mudharabah dan musyarakah pada BPRS dapat lebih ditingkatkan lagi karena pembiayaan ini mendukung tumbuhnya sektor-sektor usaha. Sehingga prosedur yang telah diterapkan oleh BPRS dalam meminimalisir perilaku moral bazard sebagai langkah penyelamatan agar tidak terjadi kerugian. Adapun untuk dapat meminimalisir resiko pembiayaan tersebut, maka perlu mengetahui faktor-faktor yang mendorong terjadinya moral hazard.

Faktor-faktor yang mendorong terjadinya moral hazard disebabkan oleh faktor nasabah dan lembaga keuangan itu sendiri. Faktor nasabah cendrung terjadi karena kepentingan pribadinya. Sedangkan faktor lembaga keuangan, karena kurangnya sikap kewaspadaan dari manajeman lembaga keuangan dalam memberikan dana sehingganya menimbulkan sisi moral hazard kepada nasabah. Hal tersebut dikarenakan tidak optimalnya sistem monitoring, asymmtric informasi, dan keterbatasan cakupan isi kontrak.

\section{DAFTAR PUSTAKA}

Ali, Salman Syed, and Islamic Research and Training Institute, eds. Islamic Capital Markets: Products, Regulation \& Development: Proceedings of International Conference. Jeddah: Islamic Research and Training Institute, Islamic Development Bank, 2008.

Antonio, Muhammad Syafi'i. Bank Syariah Dari Teori Ke Praktik. Jakarta: Gema Insani, 2004.

Asmirawati, and Sumarlin. "PERILAKU MORAL HAZARD NASABAH PADA PEMBIAYAAN BERBASIS BAGI HASIL PADA PERBANKAN SYARIAH." LAA MAISYIR : Jurnal Ekonomi Islam 5, no. 1 (June 15, 2018): 121-44. https://doi.org/10.24252/laamaisyir.v5i1a6. 
Darmawi, Herman. Manajemen Risiko. Jakarta: Bumi Aksara, 2010.Indonesia, Ikatan Akutansi. "PSAK 105," 2007. . "PSAK 106," 2007.

Karim, Adiwarman A. Bank Islam Analisis Fiqib Dan Keuangan. Jakarta: PT Raja Grafindo Persada, 2013.

Kasidi. Manajemen Risiko. Semarang: Penerbit Ghalia Indonesia, 2010.

Keuangan, Otoritas Jasa. Statistik Perbankan Syariah, Sharia Banking Statistic, 2019.

Masyhuri, and Zainuddin. Metodelogi Penelitian Pendekatan Praktis Dan Aplikatif. Bandung: PT. Refika aditama, 2011.

Maulida, Dwi Agustin, and Abdul Mukti Thabrani. "MEMINIMALISIR RESIKO MORAL HAZARD PADA PEMBIAYAAN MUDHARABAH DI KOPERASI SYARIAH NURI JAWA TIMUR (KSN JATIM) PLAKPAK KECAMATAN PEGANTENAN PAMEKASAN.” IQTISHADLA: Jurnal Ekonomi \& Perbankan Syariab 2, no. 2 (December 31, 2015): 191. https://doi.org/10.19105/iqtishadia.v2i2.866.

Moleong, Lexi J. Metodologi Penelitian Kualitatif. Bandung: PT Remaja Rosdakarya, 2014.

Narbuko, Cholid, and Abu Achmadi. Metodologi Penelitian. Jakarta: PT. Bumi Aksara, 2007.

Nasution, Mustafa Edwin, and Ranti Wiliasih. "PROFIT SHARING DAN MORAL HAZARD DALAM PENYALURAN DANA PIHAK KETIGA BANK UMUM SYARIAH DI INDONESIA.” Jurnal Ekonomi Dan Pembangunan Indonesia 7, no. 2 (January 1, 2007): 23155. https://doi.org/10.21002/jepi.v7i2.175.

Suciningtias, Siti Aisiyah. "Indikasi Moral Hazard Pada Pembiayaan Mudharabah Dan Murabahah Pada Bank Umum Syariah Di Indonesia." Jurnal Dinamila Ekonomi Dan Bisnis 14, no. 01 (March 2017).

Taswan. Manajemen Perbankan Konsep, Tehnik \& Aplikasi. Yogyakarta: UPP STIM YKPN, 2010.

Taufik, Iqbal, and Saija. Dinamika Hukum Islam Indonesia. Yogyakarta: Deepublish, 2016.

Wahyu dkk, Imam. Manajemen Risiko Bank Islam. Jakarta: Penertbit Salemba Empat, 2013.

Yusmad, Muammar Arafat. Aspek Hukum Perbankan Syariah Dari Teori Ke Praktik. Yogyakarta: Budi Utama, 2018. 